\title{
Function of Heparan Sulfate in Pluripotent Stem Cells 多能性幹細胞におけるへパラン硫酸の機能
}

\author{
Hirano, Kazumi; and Nishihara, Shoko \\ Department of Bioinformatics, Faculty of Engineering, Soka University, 1-236 Tangi, Hachioji, Tokyo 192-8577, Japan \\ FAX: +82-426-91-2495, E-mail: shoko@soka.ac.jp
}

(Received on May 2, 2014, accepted on May 27, 2014)

Key Words: heparan sulfate, sulfation, embryonic stem cell, self-renewal, differentiation

\begin{abstract}
Heparan sulfate (HS) is one of glycosaminoglycan (GAG) and is composed of GlcA-GlcNAc repeating disaccharide units, which are sulfated by several sulfotransferases. Sulfation structure of HS results in various patterns and can facilitate binding to each morphogen and growth factor, such as BMPs, Wnts, FGFs, and EGFs, and regulate the associated signaling pathways. It was previously revealed that HS and its sulfation are required for maintenance and differentiation of mouse embryonic stem (ES) cells through FGF4, BMP4, and Wnt signaling. However, most of the functions of HS sulfation patterns are still unknown. In this mini-review, we describe and discuss the functions of HS, including its sulfation pattern in pluripotent stem cells.
\end{abstract}

要 約

ヘパラン硫酸はグリコサミノグライカンの一つであり、 GlcA-GlcNAcの二糖繰り返しユニットから構成され、複数 の硫酸転移酵素により硫酸化される。ヘパラン硫酸の硫酸 化構造にはさまざまなパターンがあり、骨形成タンパク質 (BMP)、Wnt、線維芽細胞成長因子（FGF）、上皮成長因子 (EGF) などのモルフォゲンや成長因子と結合してシグナル 経路を調節している。以前、われわれや他の研究グループは、 ヘパラン硫酸とその硫酸化がFGF4、BMP4、Wnt シグナルを 介してマウス肧性幹細胞 (ES 細胞) の維持と分化を制御し ていることを明らかにした。しかし、へパラン硫酸の硫酸化 パターンが持つ機能の多くはいまだに不明である。本稿で は、多能性幹細胞におけるへパラン硫酸とその硫酸化パター ンの機能を紹介する。

\section{A. Synthesis of Heparan Sulfate}

Heparan sulfate (HS) is one of glycosaminoglycan (GAG) that ubiquitously exists in the extracellular matrix and on the cell surface. Many molecules that are important for development, including fibroblast growth factors (FGFs), Wnts, and bone morphogenic proteins (BMPs), can bind to specific sulfated regions of HS chains and regulate signaling by binding HS and signal-associated molecules (Fig. 1) (1).

In proteoglycans that comprise GAGs and core proteins, the HS chains are covalently attached to Ser residues in the core proteins through the linkage region $\mathrm{GlcA} \beta 1 \rightarrow 3 \mathrm{Gal} \beta 1 \rightarrow 3 \mathrm{Gal} \beta 1 \rightarrow$ $4 \mathrm{Xyl} \beta 1$-O-Ser (Fig. 2) (2). Recently, it has been reported that synthesis of the linkage region is enhanced by FAM20B, which is a kinase that phosphorylates the Xyl residue in the linkage region (3). Additionally, HS and chondroitin sulfate (CS) synthesis is acquired for dephosphorylation of the Xyl residue in the linkage region by 2-phosphoxylose phosphatase (XYLP). HS chains are synthesized in the Golgi apparatus by several enzymes, including members of the hereditary multiple exostoses (EXT) protein family, which elongate the HS chain by adding repeating disaccharide units of D-glucuronic acid- $N$-acetyl-D-glucosamine $(-4 \mathrm{GlcA} \beta 1 \rightarrow$ 4GlcNAc $\alpha 1-)_{n}$.

These repeating units are then differentially modified by

\section{A. ヘパラン硫酸の生合成}

ヘパラン硫酸は、グリコサミノグライカン $(\mathrm{GAG})$ の 一つであり、細胞外マトリクスや細胞表面の広範囲に発現し ている。線維芽細胞成長因子 (fibroblast growth factor: FGF)、 Wnt、骨形成タンパク質 (bone morphogenetic protein : BMP) などの発生において重要な分子は、へパラン硫酸の特異的な 硫酸化領域に結合する。ヘパラン硫酸は、その結合を調節す ることによりシグナル伝達を制御している（図 1) (1)。

グリコサミノグライカンとコアタンパク質から構成され るプロテオグライカンにおいて、ヘパラン硫酸はリンケージ 領域（GlcA $\beta 1 \rightarrow 3 \mathrm{Gal} \beta 1 \rightarrow 3 \mathrm{Gal} \beta 1 \rightarrow 4 \mathrm{Xyl} \beta 1-O-\mathrm{Ser} ）$ をして、 コアタンパク質のセリン残基に共有結合する（図2）(2）。最 近、リンケージ領域中のキシロース（Xyl）残基のリン酸化 酵素であるFAM20Bにより、リンケージ領域の合成が増強 されることが報告された (3)。さらに、ヘパラン硫酸とコン ドロイチン硫酸の合成には、2-リン酸化キシロース脱リン酸 化酵素（XYLP）による、リンケージ領域のXylの脱リン酸 化が必要であることも合わせて報告された。へパラン硫酸 は、ゴルジ体において遺伝性多発性外骨腫の原因遺伝子であ るEXTタンパク質ファミリーなどにより合成される（図3）。 EXTは、繰り返し二糖ユニットであるグルクロン酸- $N$-アセ チルグルコサミン $(-4 \mathrm{GlcA} \beta 1 \rightarrow 4 \mathrm{GlcNAc} \alpha 1-)_{n}$ を転移してへ パラン硫酸を伸長させる。

種々の構造的・機能的に多様な合成物を生み出すため 


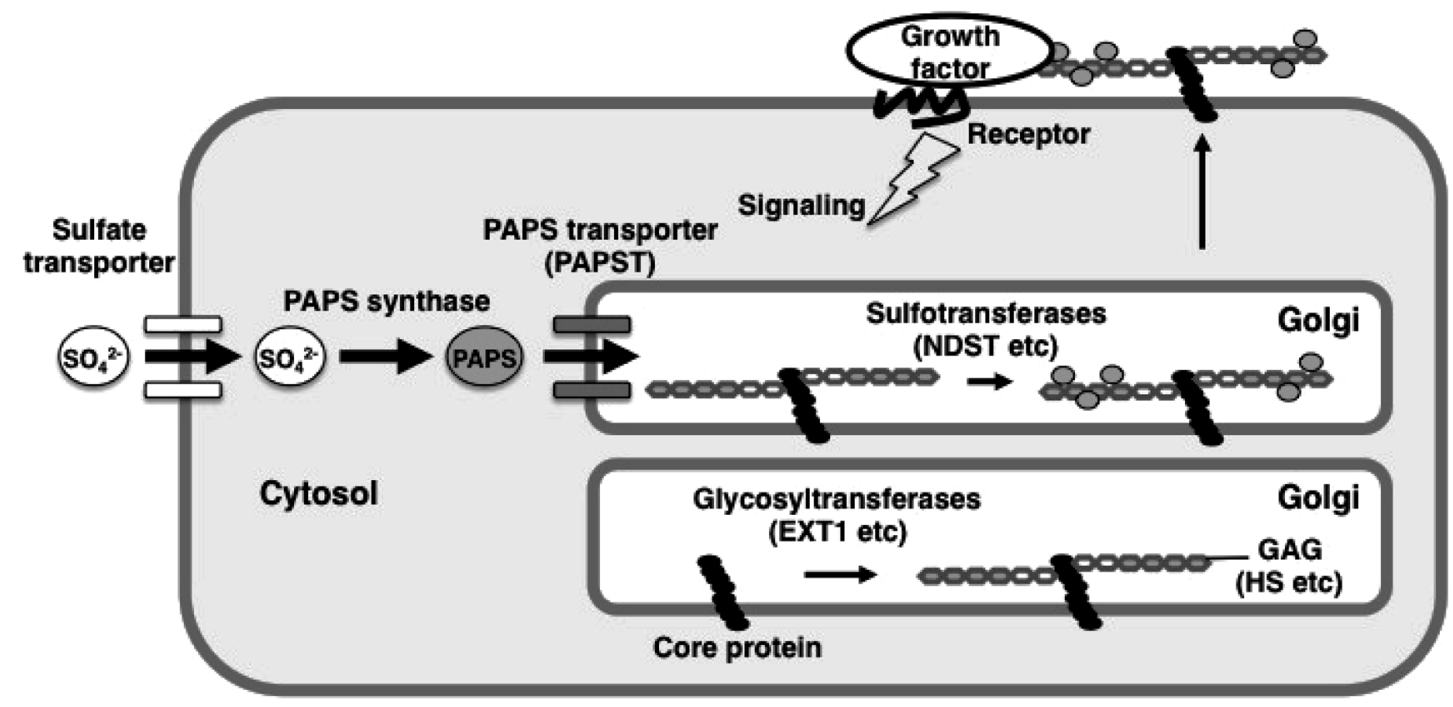

Fig. 1. Scheme of sulfate modification and signal regulation by sulfated glycosaminoglycan. A sulfate ion is transported into the cytosol by the sulfate transporter. The transported sulfate ion is converted into 3'-phosphoadenosine 5'-phosphosulfate (PAPS) by PAPS synthase. PAPS is transported into the Golgi apparatus through PAPS transporters (PAPSTs). Numerous sulfotransferases transfer sulfate from PAPS to the appropriate positions in glycans, such as glycosaminoglycans (GAGs). Sulfate-modified GAGs bind to various growth factors and support signal transduction.

epimerization and sulfation to produce a wide range of structurally and functionally diverse compounds (Fig. 3) (2). $N$-deacetylase $/ N$ sulfotransferase (NDST), which transfers sulfate to the $N$-position of GlcNAc and initiates whole sulfation of HS, is a key enzyme for initiating the sulfation because subsequent $O$-sulfations at various positions occur near $N$-sulfation (4). After $N$-sulfation, glucuronyl C5-epimerase changes GlcA into iduronic acid (IdoA) by epimerization of $\mathrm{COOH}$ at position 5 of GlcA. HS 2-O-sulfotransferase (HS2ST) transfers sulfate to position 2 of GlcA/IdoA, and HS 6-Osulfotransferase (HS6ST) transfers sulfate to position 6 of GlcNAc/ GlcNS. Finally, HS 3-O-sulfotransferase (HS3ST) transfers sulfate to position 3 of GlcNS (5). Although this 3-O-sulfation is a relatively rare modification in HS sulfation, certain specific signal ligands and receptors bind to this sulfated structure and regulate the associated signaling pathways (6-8).

\section{B. Embryonic Stem Cells and Signaling to Maintain Pluripotency}

Embryonic stem (ES) cells are derived from the inner cell mass (ICM) of pre-implantation blastocysts $(9,10)$, have the characteristic features of self-renewal and pluripotency, and are able to differentiate into all cell types derived from different germ layers (11-13). Engraftment of functional somatic cells induced from ES cells is a promising approach in regenerative medicine for functional recovery after injury. However, this topic is not easily studied because of ethical problems associated with using human embryos to establish human ES cells and the potential issue of im-
に、これらへパラン硫酸の繰り返しユニットは、エピマー化 や硫酸化といった修飾を差次的に受ける（図3）(2)。脱 $N$-ア セチル $/ N$-硫酸転移酵素（NDST）は、GlcNAcの $N$ 位を硫酸 化し、ヘパラン硫酸の全体の硫酸化を惹起する。さまざまな 位置の $O$ 位の硫酸化は $N$ 位の硫酸化の近傍で起こるために、 NDST はへパラン硫酸の硫酸化修飾の開始を担う重要な酵素 であると言える $(4)$ 。N位の硫酸化の後、グルクロニルC5エピメラーゼは、GlcAの5位の $\mathrm{COOH}$ をエピマー化させる ことでイズロン酸（IdoA）へと変換する。へパラン硫酸 $2-O$ 硫酸転移酵素（HS2ST）は、GlcA/IdoAの2 位に、ヘパラン 硫酸 6- $O$ 硫酸転移酵素（HS6ST）は GlcNAc/GlcNS の 6 位に 硫酸基を転移する。さらに、ヘパラン硫酸 3- $O$ 硫酸転移酵素 （HS3ST）が、GlcNSの3 位に硫酸基を転移する (5)。この 3 位の硫酸化はへパラン硫酸の硫酸化修飾において相対的に稀 な修飾であるが、特異的なシグナルリガンドや受容体と結合 し、関連するシグナル経路を制御していることが報告されて いる $(6-8)$ 。

\section{B. ES 細胞の維持と分化に働くシグナル}

胚性幹（ES）細胞は、着床前胚盤胞の内部細胞塊（inner cell mass: ICM) から樹立され $(9,10)$ 、自己複製能と多 分化能を維持している。さらにES細胞は、異なる肧葉に由 来するすべての細胞に分化することが可能な幹細胞である (11-13)。ES細胞から適切に分化誘導された体細胞の移植は、 傷害や疾患などにより正常な働きを失った組織・臓器の機能 回復を目指す再生医療への有望なアプローチである。しかし ながら、ヒト ES 細胞を樹立するためにヒト胚を使用すると いう倫理的な問題、さらに移植に伴う免疫拒絶の問題がある ため、再生医療への応用は容易ではなかった。人工多能性 


\section{Core protein}

\section{Phosphorylation by FAM20B enhances the synthesis of linkage region}
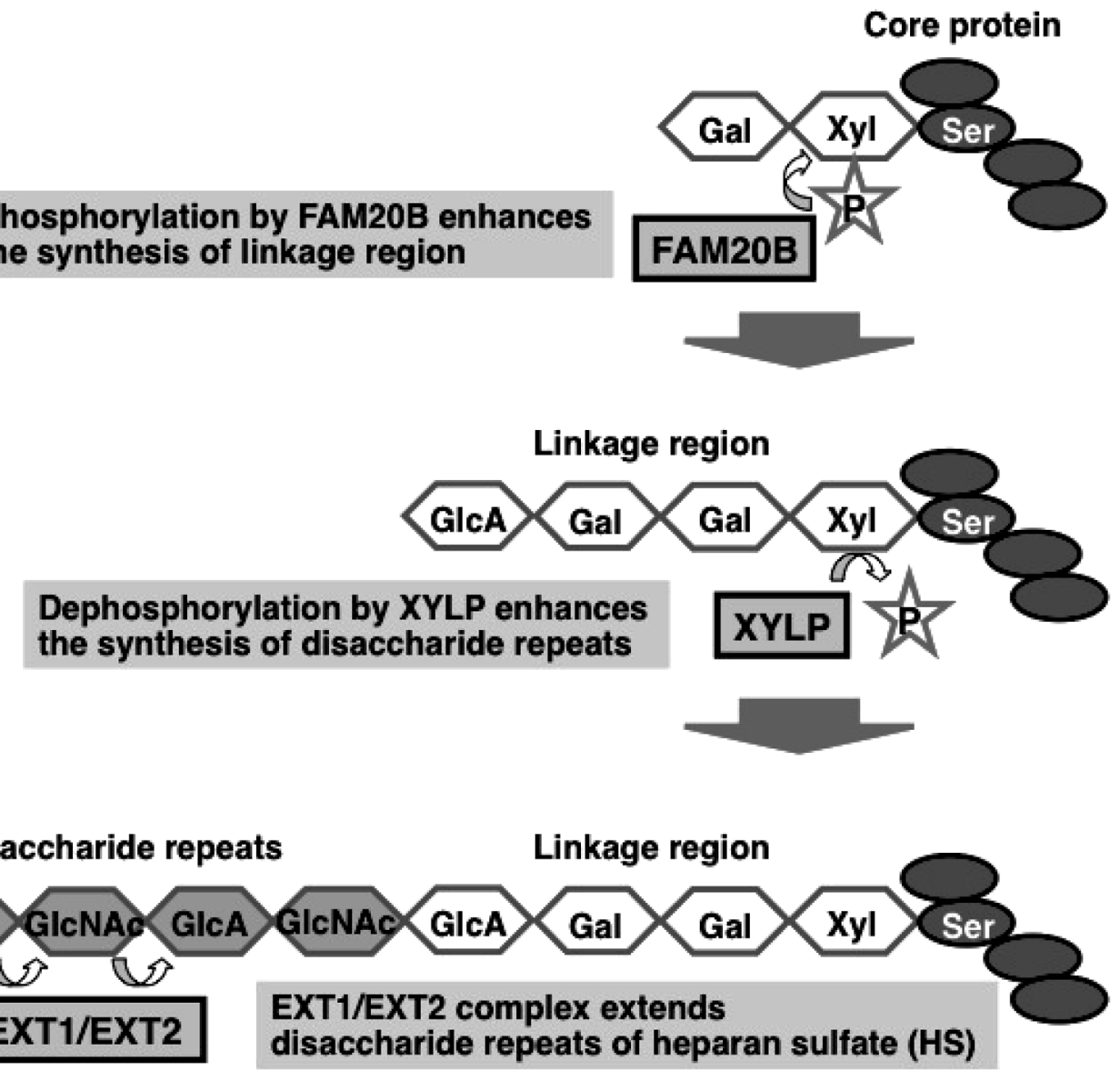

Fig. 2. Scheme of synthesis of heparan sulfate. In proteoglycans composing GAGs and core proteins, the heparan sulfate (HS) chains are covalently attached to Ser residues in the core proteins through the linkage region $\mathrm{GlcA} \beta 1 \rightarrow 3 \mathrm{Gal} \beta 1 \rightarrow 3 \mathrm{Gal} \beta 1 \rightarrow 4 \mathrm{Xyl} \beta 1$ - $O$-Ser. Synthesis of the linkage region is enhanced by FAM20B, which is a kinase that phosphorylates the Xyl residue in the linkage region. Effective synthesis of HS is acquired for the dephosphorylation of Xyl residue in the linkage region by 2-phosphoxylose phosphatase (XYLP). The EXT1/ EXT2 complex generates disaccharide repeats of HS.

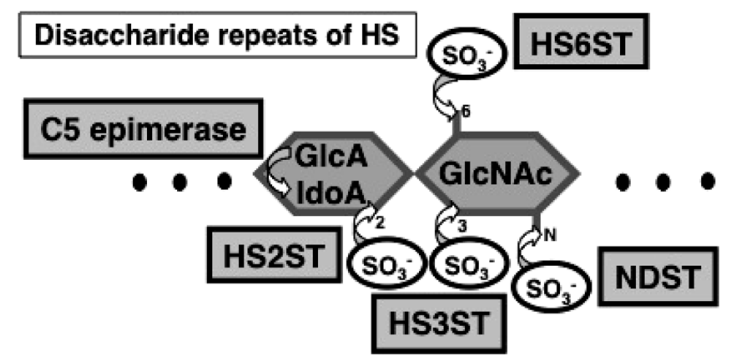

Fig. 3. Scheme of sulfate modification of heparan sulfate. The heparan sulfate (HS) chain is received sulfate modification by sulfotransferases. $\mathrm{N}$-deacetylase/ $\mathrm{N}$-sulfotransferase (NDST), which transfers sulfate to the $N$-position of GlcNAc and initiates whole sulfation of HS; subsequently, $O$-sulfations at various positions occur near $N$-sulfation. After $N$-sulfation, glucuronyl C5-epimerase changes GlcA into iduronic acid (IdoA) by epimerization of $\mathrm{COOH}$ at position 5 of GlcA. HS 2-O-sulfotransferase (HS2ST) transfers sulfate to the 2 position of GlcA/IdoA, and 6-O-Sulfotransferase (HS6ST) also transfers sulfate to the 6 position of GlcNAc/ GlcNS. Finally, 3-O-sulfotransferase (HS3ST) transfers sulfate to the 3 position of GlcNS.

mune rejection. Induced pluripotent stem (iPS) cells are ES-like pluripotent stem cells induced from somatic cells that solved problems associated with using human embryos $(14,15)$. Clarifying the mechanisms of ES cell differentiation can accelerate clinical application of ES and iPS cells as well as provides basic knowledge regarding the early developmental process.

Leukemia inhibitory factor (LIF) $(16,17)$, a known extrinsic factor, plays an important role in maintaining self-renewal of
幹（iPS）細胞は、体細胞から誘導された、ES 細胞に類似し た多能性幹細胞で、この細胞の発見により、これらの問題の

一部を解決した $(14,15)$ 。 ES 細胞の分化機構を明らかにする ことは、初期発生に関する基礎知識を提供するだけでなく、 ES 細胞とiPS 細胞を用いた臨床応用の早期実現につながる。

外因性因子として知られる白血病抑制因子（leukemia inhibitory factor: LIF) $(16,17)$ は、 signal transduction and activator of transcription 3（STAT3）の活性化を介してマウス ES 細 
mouse ES cells via signal transduction and activator of transcription 3 (STAT3) activation (18). Another extrinsic factor, BMP4, acts in synergy with LIF to maintain self-renewal by modulating the Smad-mediated induction of the inhibitor of differentiation (Id) gene (19). Canonical Wnt signaling via $\beta$-catenin also plays a role in the regulation of self-renewal through Nanog expression, which is a key transcription factor involving the pluripotent core circuit (20-22). On the other hand, Lyashenko et al. reported that selfrenewal of $\beta$-catenin-deficient mouse ES cells is maintained, indicating that $\beta$-catenin is not required for self-renewal (23). Ying et al. demonstrated that maintenance of the ground state of mouse ES cells requires inhibition of GSK3 $\beta$, which is a downstream factor of Wnt signaling that degrades $\beta$-catenin and down-regulates Wnt signaling (24). In other words, this report suggested that the promotion of Wnt signaling is fundamental to sustain pluripotency of mouse ES cells. However, there is room for debate regarding the function of Wnt signaling in mouse ES cells.

In the differentiation of mouse ES cells, both BMP and Wnt signaling have important functions (25). BMP/Smad signaling is essential for determining if cells will be ectodermal or mesodermal $(25,26)$. When BMP/Smad signaling is activated in mouse ES cells, ectodermal differentiation is inhibited and mesodermal differentiation is accelerated. Wnt $/ \beta$-catenin signaling promotes mesodermal differentiation in mouse ES cells $(27,28)$. FGF4 is produced in an autocrine fashion in mouse ES cells, and FGF4/extracellular signal-regulated kinase (ERK) signaling contributes to the differentiation of mouse ES cells into neural and mesodermal lineages (29). Moreover, ERK activation is inhibited by BMP signaling via dual specificity phosphatase-9 (DUSP9), which dephosphorylates ERK (30).

\section{The Carbohydrate Chain on the ES Cell Surface}

ES cells express various carbohydrate antigens as undifferentiated markers on the cell surface and include antigens such as stage-specific embryonic antigen-1 (SSEA-1), SSEA-3, SSEA-4, SSEA-5, GloboH, TRA-1-60 antigen, and TRA-1-81 antigen (3135). Previous data suggest that the HS sulfation pattern changes during differentiation of mouse $\operatorname{ES}$ cells $(7,36)$, which suggests that the expression of GAG, including its sulfation pattern, can be a marker reflecting the state of pluripotent stem cells. However, most functions of these carbohydrate structures have not been clarified yet.

\section{The Function of the HS Chain in Mouse ES Cells}

The control of sulfated HS structures is considered essential for spatiotemporal regulation of cellular differentiation and growth throughout development. Indeed, in EXT1 or EXT2-deficient mice,
胞の自己複製能の維持に重要な役割を果たす $(18)$ 。他の外因 性因子として知られる骨形成タンパク質-4（BMP4）は、LIF と協調的に働き、Smadを介したinhibitor of differentiation (Id) 遺伝子の発現の誘導を調整することで、マウス ES 細胞の自 己複製能を維持している(19)。

$\beta$-catenin Æする古典的なWntシグナルは、多能性を制 御する転写因子群（コアサーキット）の主要な転写因子であ るNanogの発現を通じてマウス ES 細胞の自己複製能の制御 を果たしている(20-22)。一方、Lyashenkoらは、 $\beta$-cateninを 欠損させたマウス ES 細胞の自己複製能が維持されているこ とを報告した。これは、 $\beta$-cateninが自己複製能の維持に必須 でないことを示していた $(23)$ 。また、Yingらは、マウスES 細胞の基底状態の維持に、Wnt シグナルの下流の因子である GSK3 $\beta$ (GSK3 $\beta$ は、 $\beta$-cateninを分解してWntシグナルを抑 制する）の阻害が必要であることを報告した(24)。つまり、 Wnt シグナルの促進が、マウス ES 細胞の多能性の維持に必 要であることを示した。このように、Wntシグナルのマウ ス ES 細胞の自己複製能への関与はいまだ議論の余地があり、 統一的な見解が得られていないのが現状である。

さらに、BMPと Wnt シグナルはマウス ES 細胞の分化に おいても重要な役割を担っている $(25)$ 。 BMP/Smadシグナル は、中胚葉または外胚葉への細胞運命決定に必須である $(25$, 26)。BMP/Smad シグナルが活性化しているとき、外肧葉分 化は抑制され、中肧葉分化は促進される。Wnt $/ \beta$-catenin シグ ナルは、マウス ES 細胞の中肧葉分化を促進する $(27,28)$ 。マ ウス ES 細胞において FGF4は自己分泌され、FGF4/extracellular signal-regulated kinase（ERK）シグナルは、神経、中肧葉 系列への分化を促進する(29)。ERKの活性化 (リン酸化) は、 ERKの脱リン酸化酵素である dual specificity phosphatase-9 （DUSP9）を介したBMP/Smad/DUSP9 シグナルにより阻害さ れる $(30)$ 。

\section{ES細胞表面の糖鎖}

ES 細胞は、ステージ特異的肧抗原-1 (stage-specific embryonic antigen-1: SSEA-1)、SSEA-3、SSEA-4、SSEA-5、GloboH、TRA-1-60 抗原、TRA-1-81 抗原など、未分化状態で特徴 的なさまざまな細胞表面糖鎖抗原を発現している(31-35)。 以前、われわれと他のグループは、マウスES細胞の分化に 伴い、ヘパラン硫酸の硫酸化パターンが変化することを示し た $(7,36)$ 。これは、ヘパラン硫酸、コンドロイチン硫酸、ケ ラタン硫酸などのグリコサミノグライカンの発現、およびそ れらの硫酸化パターンが多能性幹細胞の状態を反映するマー カーとなりうることを意味している。しかし、これら糖鎖構 造のマウス ES 細胞、さらにヒト多能性幹細胞であるヒト ES/ iPS 細胞における機能はほとんど明らかになっていない。

\section{D. マウスES細胞におけるへパラン硫酸鎖の機能 ヘパラン硫酸の硫酸化構造のコントロールは、発生過程 に扔ける細胞の分化と増殖の時空間的な制御に必要不可欠で あると考えられている。実際、EXT1、EXT2欠損マウス、つ}


namely mice lacking HS chains, the embryo fails to reach gastrulation and dies (37). Thus, from the loss of function study, it was revealed that HS is essential for early development. For addressing HS function in early development, studies used and analyzed genetically modified mouse ES cells. HS and its related genes are expressed in undifferentiated mouse ES cells and change during differentiation into extraendoderm and three germ layers, including Sox1-positive ectoderm and Flk-positive mesoderm $(36,38,39)$.

For function analysis of HS, we performed EXT1 transient knockdown in mouse ES cells. EXT1-knockdown ES cells have short HS chains and reduce Wnt signaling and undifferentiation. We also found that HS, but not CS, is required for self-renewal of mouse ES cells through Wnt signaling (22). FGF4 and BMP4 signaling did not change in this study. Moreover, HS degradation by heparitinase caused reduction of FGF, BMP4, and Wnt signaling in mouse ES cells. These results indicate that HS chains help facilitate signal transduction as a co-receptor and maintain self-renewal. On the other hand, other groups reported that EXT1-deficient ES cells, which have no HS chains, could not differentiate $(36,40$ $42)$. In the EXT1-deficient ES cells, inhibition of Nanog expression via FGF4 signaling was eliminated because FGF4 signaling, the differentiation trigger, could not work with deficient HS chains. These results indicate that HS chains are also necessary for the initiation of differentiation, and these reports suggest that HS has pleiotropic functions depending on the length of the chain.

\section{E. The Function of Sulfation of HS in Mouse ES Cells}

The nucleotide sulfate, namely 3 '-phosphoadenosine 5' -phosphosulfate (PAPS), is a substrate for the sulfation of glycans or proteins and is synthesized in the cytoplasm by PAPS synthase (Fig. 1). PAPS transporter (PAPST), localized in the Golgi membrane, transports PAPS into the Golgi apparatus. Numerous sulfotransferases transfer sulfate from transported PAPS to the appropriate positions on proteins or glycans, such as GAG. To analyze the function of sulfation, we performed PAPST1,2-knockdown in mouse ES cells (43). PAPST1,2-knockdown, which reduces the level of sulfation of all sulfated lipids, proteins, and glycans, including HS, causes the inhibition of FGF2, FGF4, BMP4, and Wnt signaling, and promotes neural differentiation. Chemical inhibition of sulfation by chlorate treatment accelerates neural differentiation of mouse ES cells (44). Furthermore, NDST1,2-knockdown, which only reduces the sulfation of HS, also causes suppression of FGF2, FGF4, BMP4, and Wnt signaling and decreased self-renewal. These data indicate that the sulfation of proteins or glycans, especially HS, is essential to regulate signaling and maintain selfrenewal of mouse ES cells.

Previous studies used NDST1,2-knockout ES cells to eluci-
まりへパラン硫酸が合成されないマウスは、原腸陥入不全を 起こし、胎生致死の表現型を示す (37)。この機能欠損の研究 から、へパラン硫酸は初期発生に重要な役割を担っているこ とが明らかになった。初期発生におけるへパラン硫酸の働き を知るために、われわれや他のグループは、遺伝子改変マウ ス ES 細胞を使用し解析した。ヘパラン硫酸やへパラン硫酸 関連遺伝子は未分化性を維持したマウス ES 細胞で発現して おり、それらの発現は、胚体外内胚葉や、Sox1 陽性外胚葉、 Flk 陽性中胚葉を含む三胚葉への分化に伴い変化する $(36,38$, 39)。

ヘパラン硫酸の機能解析のために、われわれは、マウ ス $\mathrm{ES}$ 細胞の EXT1 一過的にノックダウンした。EXT1ノッ クダウン ES 細胞では、ヘパラン硫酸鎖が短くなり、Wnt シ グナルおよび未分化性が低下していたことから、へパラン 硫酸（コンドロイチン硫酸ではなく）がWntシグナルを介し てマウス ES 細胞の自己複製能の維持に必要であることが明 らかになった (22)。このノックダウン細胞において、FGF4、 BMP4 シグナルは変化していなかった。さらに、へパリチ ナーゼによりマウス ES 細胞表面上のヘパラン硫酸を分解す ると、Wntシグナルだけでなく、FGF、BMP シグナルの低下 を引き起こした。この知見は、へパラン硫酸が共受容体とし てシグナル伝達を補佐し、マウス ES 細胞の自己複製能を維 持していることを示している。一方、他の研究グループは、 $E X T 1$ 欠損 $\mathrm{ES}$ 細胞、つまりへパラン硫酸が全く発現してい ないES 細胞は分化することができないことを報告した $(36$, 40-42)。EXT1 欠損 ES 細胞において、分化の引き金である FGF4 シグナルがへパラン硫酸の欠損により機能せず、FGF4 シグナルを介したNanogの発現抑制が解除されていたことか ら、へパラン硫酸は分化の開始に必要であることが分かっ た。これらの報告は、へパラン硫酸が鎖長に依存した多面的 な機能を有していることを示唆している。

\section{E. マウスES細胞におけるへパラン硫酸の硫酸化修飾の機} 能

3'-ホスホアデノシン-5'-ホスホ硫酸（PAPS）は、糖鎖 やタンパク質の硫酸化修飾の基質であり、PAPS 合成酵素に より細胞質で合成される（図 1)。ゴルジ体の膜に存在する PAPS 輸送体（PAPST）は、PAPSをゴルジ体内腔へと輸送す る。さまざまな硫酸転移酵素は、ゴルジ体内腔へと運ばれ たPAPSから硫酸基をタンパク質やグリコサミノグリカンな どの糖鎖の適切な位置へと転移する。われわれは、硫酸化の 機能を解析するために、PAPST1,2のノックダウンを行った (43)。PAPST1,2のノックダウンは、硫酸化脂質、硫酸化夕 ンパク質、硫酸化糖鎖など、ヘパラン硫酸を含むすべての硫 酸化のレベルを低下させ、それに伴いFGF2,4、BMP4、Wnt シグナルが低下し、神経分化を促進させた。塩素酸塩を用い た硫酸化の化学的抑制もまた、マウス ES 細胞の神経系への 分化を促進した (44)。さらに、NDST1,2のノックダウンは、 ヘパラン硫酸の硫酸化のみを低下させ、FGF2,4、BMP4、 Wnt シグナルをPAPT1,2のノックダウンと同様に抑制し、自 己複製能を低下させた。これらの知見は、タンパク質や糖鎖 の硫酸化、特にヘパラン硫酸の硫酸化がシグナルの制御とマ ウス $\mathrm{ES}$ 細胞の自己複製の維持に必須であることを示してい る。

他のグループは、ヘパラン硫酸の硫酸化の機能の探索の 
date the function of HS sulfation $(45,46)$. NDST1,2-null mouse ES cells have HS with almost no sulfation, but possess HS that has a small amount of 6-O-sulfation (47). Depletion of NDST1,2 prohibited differentiation, including neural lineage differentiation, in mouse ES cells by inhibition of FGF4 signaling. These studies demonstrate that sulfation of HS regulates self-renewal and differentiation of mouse ES cells.

\section{F. The Function of Sulfation Pattern of HS in Mouse ES Cells}

Sulfation pattern in HS is formed by several sulfotransferases and changes during differentiation of mouse ES cells (36). This finding was achieved by phage display antibodies that recognize specific sulfation structures of HS $(36,48)$. However, the function of sulfation pattern of HS during differentiation of mouse ES cells is still unclear. We assume that the alterations of sulfation pattern of HS may regulate several signaling pathways and differentiation.

To identify the sulfation pattern of HS involved in the differentiation of mouse ES cells, we screened sulfotransferases by their overexpression and found that overexpression of HS3ST, an enzyme facilitating 3-O-sulfation in $\mathrm{HS}$, reduced self-renewal and promoted differentiation of mouse ES cells (7). The function of 3-O-sulfation of HS is largely unknown because large quantities of HS are required for structural analyses, and technology to quantitate 3-O-sulfation have not yet been developed. We used the HS4C3 antibody, a phage display antibody recognizing 3-O-sulfation of HS, for analysis, and revealed that 3-O-sulfation is required for differentiation into primitive endoderm, primitive ectoderm including epiblast stem cells, and subsequently the three germ layers $(7,8)$. Furthermore, 3-O-sulfation of HS associates with Fas, which is a member of the tumor necrosis factor (TNF) receptor family, and translocates intracellular Fas into lipid rafts on the mouse ES cell surface. Then, Fas/caspase-8/caspase-3 signaling is activated by the accumulation of Fas in rafts and subsequently induces the degradation of the Nanog protein, which is a key transcription factor for maintaining self-renewal and pluripotency of ES cells by activated caspase-3 $(7,49)$. Thus, we showed that 3-Osulfation of HS is a novel regulator of mouse ES cell differentiation.

\section{G. Prospective}

To date, many studies have demonstrated that HS and its sulfation pattern regulate several signaling pathways to maintain selfrenewal and pluripotency of mouse ES cells (Fig. 4). One of the remaining important issues is understanding the role of HS in human pluripotent stem cells, such as human ES and iPS cells. Mouse ES cells are defined as "naïve" pluripotent stem cells because of
ためにNDST1,2ノックアウトES細胞を用いて研究を行った $(45,46)$ 。NDST1,2 欠損 ES 細胞では、硫酸化修飾を受けてい ないへパラン硫酸がほとんどであるが、低い割合で GlcNAc の6位の硫酸化が起きている $(47)$ 。マウス ES 細胞における NDST1,2の欠損は、FGF4 シグナルの抑制を介して神経系へ の分化を阻害した $(45,46)$ 。これらの報告は、へパラン硫酸 の硫酸化はマウス ES 細胞の自己複製と分化の両者を制御し ていることを示している。

\section{F. マウスES細胞におけるヘパラン硫酸の硫酸化パターン の機能}

ヘパラン硫酸の硫酸化はいくつもの硫酸転移酵素によっ てなされ、その硫酸化パターンはマウス ES 細胞の分化過程 において変化する $(36)$ 。ヘパラン硫酸の硫酸化パターンの解 析は、へパラン硫酸の特異的な硫酸化構造を認識するファー ジディスプレイ抗体を用いて行われた $(36,48)$ 。しかし、マ ウス ES 細胞の分化時における、それぞれのへパラン硫酸の 硫酸化パターンの機能と意義はいまだに明らかになっていな い。そこで、われわれは、ヘパラン硫酸の硫酸化パターン の変化は、シグナルや分化を制御しているという想定をし た。マウス ES 細胞の分化に関与する硫酸化パターンを特定 するため、各硫酸転移酵素を過剩発現しスクリーニングを 行った。その結果、ヘパラン硫酸の 3 位に硫酸基を転移する HS3ST 過剩発現させると、マウスES細胞の自己複製が抑 制され、分化が促進することを見いだした（7)。ヘパラン硫 酸の 3 位の硫酸化（3-O硫酸化構造）の定量には、大量のへ パラン硫酸が必要であり、その定量法はまだ確立・発展して いないため、3-O硫酸化構造の機能はほとんど知られていな い。われわれは、 $\mathrm{HS} 4 \mathrm{C} 3$ 抗体（3-O硫酸化構造を特異的に認 識するファージディスプレイ抗体）を用いて $3-O$ 硫酸化構造 の機能解析を行い、3- $O$ 硫酸化構造が原始内肧葉、原始外胚 葉（エピ幹細胞の状態を含む）とそれに引き続く内・中・外 肧葉への分化に必要であることを明らかにした $(7,8)$ 。さら に、3-O硫酸化構造がFas（腫瘍壊死因子（tumor necrosis factor: TNF）受容体ファミリーの一つ）と結合し、細胞内部の Fasを脂質ラフトへと移動させることを見いだした。Fasが脂 質ラフトへ蓄積することで、Fas/caspase-8/caspase-3 シグナル が活性化し、それに引き続き、活性型 caspase-3による Nanog

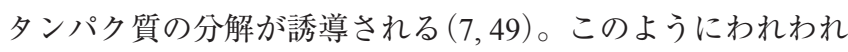
は、3-O硫酸化構造が、マウス $\mathrm{ES}$ 細胞の分化を制御する新 たな因子であることを示した。

\section{G. 展望}

これまでに、ヘパラン硫酸がマウス ES 細胞の多能性と 自己複製能の維持に働くシグナルを制御していることを、多 くの研究が証明をしている（図4）。しかし、いまだ残って いる重要な課題の一つに、ヒト ES 細胞やiPS 細胞などのヒ 卜多能性幹細胞におけるへパラン硫酸の機構の理解がある。 マウス ES 細胞は、着床前エピブラストと機能的に類似して 


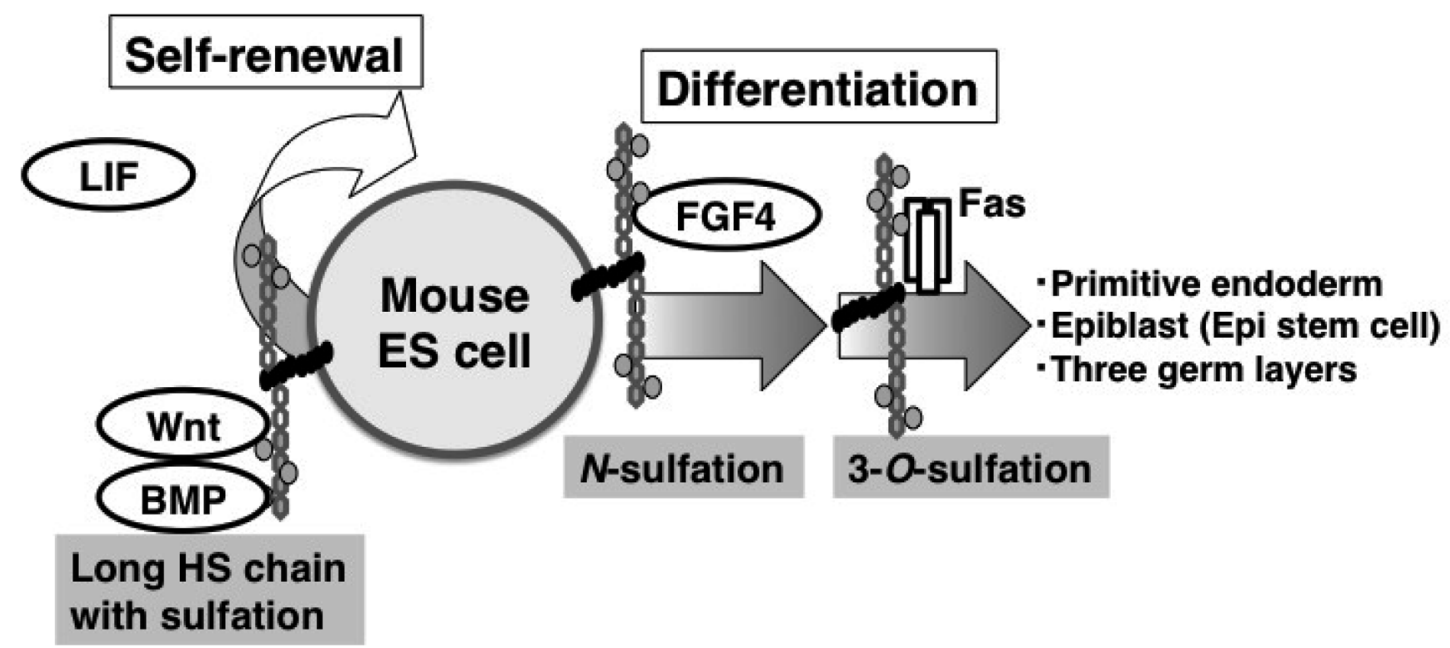

Fig. 4. The function of heparan sulfate in mouse embryonic stem cells. For maintenance of self-renewal in mouse ES cells, heparan sulfate (HS) with a long sulfated chain helps transduction of Wnt and BMP signaling as a co-receptor. LIF signaling independently works on HS. When mouse embryonic stem (ES) cells differentiate, $N$-sulfation of HS is required for FGF4 signal transduction. Fas signaling facilitates rapid differentiation by degradation of the Nanog protein after FGF4 signaling.

their functional similarity to pre-implantation epiblasts (50). On the other hand, mouse epiblast stem cells are distinguished from mouse ES cells by differences in the developmental stage; namely, that they are derived from post-implantation blastocysts. The pluripotent state of epiblast stem cells has been described as "primed" based on their post-implantation epiblast-like transcriptional and epigenetic properties (50-52). Human pluripotent stem cells, ES cells, and iPS cells share defining features with mouse epiblast stem cells in the primed state rather than mouse ES cells in the naive state. Therefore, human ES/iPS cells are believed to be primed pluripotent stem cells (50-52).

Recently, we reported that Fas signaling via 3-O-sulfation of HS is also required for the transition from naïve to primed state (8). Furthermore, we demonstrated that chemical inhibition of sulfation by chlorate accelerates neural differentiation of human iPS cells (44). These findings indicate the possibility that sulfation of GAGs, including HS, regulates self-renewal and pluripotency in humans through several signaling pathways. Other important factors of GAGs are core proteins, such as syndecans, glypicans, and agrin. Annalisa et al. reported that glypican-4, an HS proteoglycan, regulates Wnt signaling and pluripotency in mouse ES cells (53). We expect that the physiological roles of HS in pluripotent stem cells will be further elucidated in future studies.
いることから “ナイーブ” 状態の多能性幹細胞と定義される (50)。一方、着床後のエピブラストから樹立されたマウスエ ピ幹細胞は、マウス ES 細胞とは異なる発生ステージの多能 性幹細胞であり、着床後エピブラストと類似した遺伝子発 現やエピジェネティクスのパターンを持つことから“プラ イム” 状態の多能性幹細胞と定義されている (50-52)。ヒト ES/iPS 細胞は、ナイーブ状態のマウス ES 細胞ではなく、プ ライム状態のエピ幹細胞の特徴を共有する。したがって、ヒ ト ES/iPS 細胞はプライム状態の多能性幹細胞であると考え られている $(50-52) 。$

2013 年にわれわれは、ヘパラン硫酸の3-O硫酸化構造を 介したFas シグナルがナイーブ状態からプライム状態への移 行に必要であることを報告した $(8)$ 。さらに、過塩素酸によ る硫酸化の化学的抑制が、ヒト iPS 細胞の神経分化を促進す ることも証明した $(44)$ 。これらの知見は、へパラン硫酸など の GAGの硫酸化が、さまざまなシグナルを通してヒト多能 性幹細胞の自己複製・多能性を制御している可能性を示して いる。硫酸化以外の GAGの重要な因子に、コアタンパク質 (syndecan, glypican, agrin など）がある。Annalisaらは、へパ ラン硫酸プロテオグライカンの一つである glypican-4がマウ ス ES 細胞においてWntシグナルと多能性を制御していると いう知見を報告した (53)。今後、さらに多能性幹細胞におけ るへパラン硫酸の生理的意義の解明が進むことが期待され る。

\section{References}

1. Lin, X. (2004) Development 131, 6009-6021.

2. Esko, J. D., and Selleck, S. B. (2002) Annu. Rev. Biochem. 71, 435-471.

3. Koike, T., Izumikawa, T., Sato, B., and Kitagawa, H. (2014) J. Biol. Chem., in press.

4. Esko, J. D., and Lindahl, U. (2001) J. Clin. Invest. 108, 169-173.

5. Mochizuki, H., Yoshida, K., Shibata, Y., and Kimata, K. (2008) J. Biol. Chem. 283, 31237-31245. 
6. Thacker, B. E., Xu, D., Lawrence, R., and Esko, J. D. (2013) Matrix Biol., in press.

7. Hirano, K., Sasaki, N., Ichimiya, T., Miura, T., Van Kuppevelt, T. H., and Nishihara, S. (2012) PLoS ONE 7, e43440.

8. Hirano, K., Van Kuppevelt, T. H., and Nishihara, S. (2013) Biochem. Biophys. Res. Commun. 430, 1175-1181.

9. Evans, M. J., and Kaufman, M. H. (1981) Nature 292, 154-156.

10. Martin, G. R. (1981) Proc. Natl. Acad. Sci. U.S.A. 78, 7634-7638.

11. Suda, Y., Suzuki, M., Ikawa, Y., and Aizawa, S. (1987) J. Cell. Physiol. 133, 197-201.

12. Beddington, R. S., and Robertson, E. J. (1989) Development 105, 733-737.

13. Bradley, A., Evans, M., Kaufman, M. H., and Robertson, E. (1984) Nature 309, 255-256.

14. Takahashi, K., and Yamanaka, S. (2006) Cell 126, 663-676.

15. Takahashi, K., Tanabe, K., Ohnuki, M., Narita, M., Ichisaka, T., Tomoda, K., and Yamanaka, S. (2007) Cell 131, 861-872.

16. Smith, A. G., Heath, J. K., Donaldson, D. D., Wong, G. G., Moreau, J., Stahl, M., and Rogers, D. (1988) Nature 336, 688-690.

17. Williams, R. L., Hilton, D. J., Pease, S., Willson, T. A., Stewart, C. L., Gearing, D. P., Wagner, E. F., Metcalf, D., Nicola, N. A., and Gough, N. M. (1988) Nature 336, 684-687.

18. Niwa, H., Burdon, T., Chambers, I., and Smith, A. (1998) Genes Dev. 12, 2048-2060.

19. Ying, Q. L., Nichols, J., Chambers, I., and Smith, A. (2003) Cell 115, 281-292.

20. Sato, N., Meijer, L., Skaltsounis, L., Greengard, P., and Brivanlou, A. H. (2004) Nat. Med. 10, 55-63.

21. Miyabayashi, T., Teo, J. L., Yamamoto, M., McMillan, M., Nguyen, C., and Kahn, M. (2007) Proc. Natl. Acad. Sci. U.S.A. 104, $5668-5673$.

22. Sasaki, N., Okishio, K., Ui-Tei, K., Saigo, K., Kinoshita-Toyoda, A., Toyoda, H., Nishimura, T., Suda, Y., Hayasaka, M., Hanaoka, K., Hitoshi, S., Ikenaka, K., and Nishihara, S. (2008) J. Biol. Chem. 283, 3594-3606.

23. Lyashenko, N., Winter, M., Migliorini, D., Biechele, T., Moon, R. T., and Hartmann, C. (2011) Nat. Cell Biol. 13, $753-761$.

24. Ying, Q. L., Wray, J., Nichols, J., Batlle-Morera, L., Doble, B., Woodgett, J., Cohen, P., and Smith, A. (2008) Nature 453, $519-523$.

25. Loebel, D. A., Watson, C. M., De Young, R. A., and Tam, P. P. (2003) Dev. Biol. 264, 1-14.

26. Finley, M. F., Devata, S., and Huettner, J. E. (1999) J. Neurobiol. 40, 271-287.

27. Bakre, M. M., Hoi, A., Mong, J. C., Koh, Y. Y., Wong, K. Y., and Stanton, L. W. (2007) J. Biol. Chem. 282, 31703-31712.

28. Lindsley, R. C., Gill, J. G., Kyba, M., Murphy, T. L., and Murphy, K. M. (2006) Development 133, 3787-3796.

29. Kunath, T., Saba-El-Leil, M. K., Almousailleakh, M., Wray, J., Meloche, S., and Smith, A. (2007) Development 134, $2895-2902$.

30. Li, Z., Fei, T., Zhang, J., Zhu, G., Wang, L., Lu, D., Chi, X., Teng, Y., Hou, N., Yang, X., Zhang, H., Han, J. D., and Chen, Y. G. (2012) Cell Stem Cell 10, 171-182.

31. Tang, C., Lee, A. S., Volkmer, J. P., Sahoo, D., Nag, D., Mosley, A. R., Inlay, M. A., Ardehali, R., Chavez, S. L., Pera, R. R., Behr, B., Wu, J. C., Weissman, I. L., and Drukker, M. (2011) Nat. Biotechnol. 29, 829-834.

32. Liang, Y. J., Kuo, H. H., Lin, C. H., Chen, Y. Y., Yang, B. C., Cheng, Y. Y., Yu, A. L., Khoo, K. H., and Yu, J. (2010) Proc. Natl. Acad. Sci. U.S.A. 107, 22564-22569.

33. Atwood, J. A. 3rd, Cheng, L., Alvarez-Manilla, G., Warren, N. L., York, W. S., and Orlando, R. (2008) J. Proteome Res. 7, $367-374$.

34. Muramatsu, T., and Muramatsu, H. (2004) Glycoconj. J. 21, 41-45.

35. International Stem Cell Initiative, Adewumi, O., Aflatoonian, B., Ahrlund-Richter, L., Amit, M., Andrews, P. W., Beighton, G., Bello, P. A., Benvenisty, N., Berry, L. S., Bevan, S., Blum, B., Brooking, J., Chen, K. G., Choo, A. B., Churchill, G. A., Corbel, M., Damjanov, I., Draper, J. S., Dvorak, P., Emanuelsson, K., Fleck, R. A., Ford, A., Gertow, K., Gertsenstein, M., Gokhale, P. J., Hamilton, R. S., Hampl, A., Healy, L. E., Hovatta, O., Hyllner, J., Imreh, M. P., Itskovitz-Eldor, J., Jackson, J., Johnson, J. L., Jones, M., Kee, K., King, B. L., Knowles, B. B., Lako, M., Lebrin, F., Mallon, B. S., Manning, D., Mayshar, Y., McKay, R. D., Michalska, A. E., Mikkola, M., Mileikovsky, M., Minger, S. L., Moore, H. D., Mummery, C. L., Nagy, A., Nakatsuji, N., O’Brien, C. M., Oh, S. K., Olsson, C., Otonkoski, T., Park, K. Y., Passier, R., Patel, H., Patel, M., Pedersen, R., Pera, M. F., Piekarczyk, M. S., Pera, R. A., Reubinoff, B. E., Robins, A. J., Rossant, J., Rugg-Gunn, P., Schulz, T. C., Semb, H., Sherrer, E. S., Siemen, H., Stacey, G. N., Stojkovic, M., Suemori, H., Szatkiewicz, J., Turetsky, T., Tuuri, T., van den Brink, S., Vintersten, K., Vuoristo, S., Ward, D., Weaver, T. A., Young, L. A., and Zhang, W. (2007) Nat. Biotechnol. 25, 803-816.

36. Johnson, C. E., Crawford, B. E., Stavridis, M., Ten Dam, G., Wat, A. L., Rushton, G., Ward, C. M., Wilson, V., van Kuppevelt, T. H., Esko, J. D., Smith, A., Gallagher, J. T., and Merry, C. L. (2007) Stem Cells 25, 1913-1923.

37. Lin, X., Wei, G., Shi, Z., Dryer, L., Esko, J. D., Wells, D. E., and Matzuk, M. M. (2000) Dev. Biol. 224, $299-311$.

38. Baldwin, R. J., ten Dam, G. B., van Kuppevelt, T. H., Lacaud, G., Gallagher, J. T., Kouskoff, V., and Merry, C. L. (2008) Stem Cells 26, $3108-3118$.

39. Nairn, A. V., Kinoshita-Toyoda, A., Toyoda, H., Xie, J., Harris, K., Dalton, S., Kulik, M., Pierce, J. M., Toida, T., Moremen, K. W., and Linhardt, R. J. (2007) J. Proteome Res. 6, 4374-4387.

40. Holley, R. J., Pickford, C. E., Rushton, G., Lacaud, G., Gallagher, J. T., Kouskoff, V., and Merry, C. L. (2011) J. Biol. Chem. 286, $6241-6252$.

41. Kraushaar, D. C., Yamaguchi, Y., and Wang, L. (2010) J. Biol. Chem. 285, 5907-5916.

42. Kraushaar, D. C., Rai, S., Condac, E., Nairn, A., Zhang, S., Yamaguchi, Y., Moremen, K., Dalton, S., and Wang, L. (2012) J. Biol. Chem. 287, 22691-22700.

43. Sasaki, N., Hirano, T., Ichimiya, T., Wakao, M., Hirano, K., Kinoshita-Toyoda, A., Toyoda, H., Suda, Y., and Nishihara, S. (2009) PLoS ONE 4, e8262.

44. Sasaki, N., Hirano, T., Kobayashi, K., Toyoda, M., Miyakawa, Y., Okita, H., Kiyokawa, N., Akutsu, H., Umezawa, A., and Nishihara, S. (2010) Biochem. Biophys. Res. Commun. 401, 480-486.

45. Lanner, F., Lee, K. L., Sohl, M., Holmborn, K., Yang, H., Wilbertz, J., Poellinger, L., Rossant, J., and Farnebo, F. (2010) Stem Cells 28, 191-200.

46. Forsberg, M., Holmborn, K., Kundu, S., Dagälv, A., Kjellén, L., and Forsberg-Nilsson, K. (2012) J. Biol. Chem. 287, $10853-10862$.

47. Holmborn, K., Ledin, J., Smeds, E., Eriksson, I., Kusche-Gullberg, M., and Kjellén, L. (2004) J. Biol. Chem. $279,42355-42358$.

48. Lensen, J. F., Rops, A. L., Wijnhoven, T. J., Hafmans, T., Feitz, W. F., Oosterwijk, E., Banas, B., Bindels, R. J., van den Heuvel, L. P., van der Vlag, J., Berden, J. H., and van Kuppevelt, T. H. (2005) J. Am. Soc. Nephrol. 16, 1279-1288. 
49. Fujita, J., Crane, A. M., Souza, M. K., Dejosez, M., Kyba, M., Flavell, R. A., Thomson, J. A., and Zwaka, T. P. (2008) Cell Stem Cell 2, 595-601.

50. Nichols, J., and Smith, A. (2009) Cell Stem Cell 4, 487-492.

51. Brons, I. G., Smithers, L. E., Trotter, M. W., Rugg-Gunn, P., Sun, B., Chuva de Sousa Lopes, S. M., Howlett, S. K., Clarkson, A., Ahrlund-Richter, L., Pedersen, R. A., and Vallier, L. (2007) Nature 448, 191-195.

52. Tesar, P. J., Chenoweth, J. G., Brook, F. A., Davies, T. J., Evans, E. P., Mack, D. L., Gardner, R. L., and McKay, R. D. (2007) Nature 448, $196-199$.

53. Fico, A., De Chevigny, A., Egea, J., Bösl, M. R., Cremer, H., Maina, F., and Dono, R. (2012) Stem Cells 30, $1863-1874$.

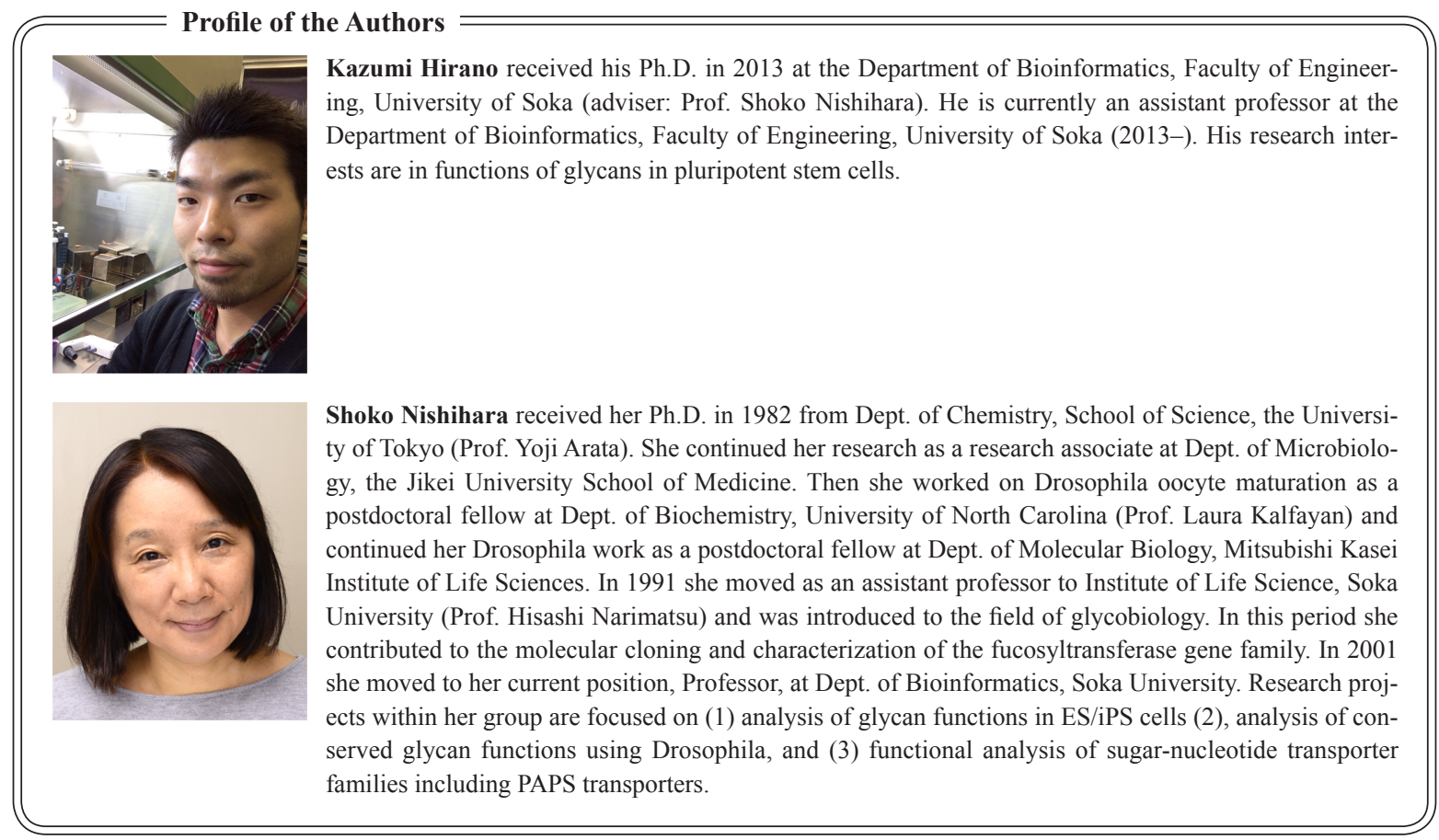

